\title{
Pengembangan Permainan Pecah Piring Sintren: Pemanfaatan Olahraga Tradisional Pada Pembelajaran untuk Meningkatkan Kemampuan Motorik Kasar Anak
}

\author{
Kamaludin $^{1}$, Ngadiman $^{1}$, Rifqi Festiawan ${ }^{{ }^{*}}$, Indra Jati Kusuma ${ }^{1}$, Ayu Rizky Febriani ${ }^{1}$ \\ ${ }^{1}$ Program Studi Pendidikan Jasmani, Universitas Jenderal Soedirman, Indonesia.
}

\section{Info Artikel}

Sejarah Artikel:

Diterima April 2020

Disetujui April 2020

Dipublikasikan Mei 2020

\section{Keywords:}

Permainan, Olahraga Tradisional, Motorik Kasar, Pecah Piring Sintren

\begin{abstract}
Abstrak
Saat ini permainan tradisional mulai jarang dimainkan anak-anak seiring dengan perkembangan zaman, padahal beberapa studi menyebutkan bahwa permainan tradisional memiliki peran yang sangat penting dalam merangsang perkembangan motorik kasar yang dimiliki oleh setiap anak. Penelitian ini bertujuan untuk menciptakan produk permainan baru dari modifikasi olahraga tradisional yang layak digunakan dan berpotensi dapat mengembangkan kemampuan motorik kasar anak usia 9 - 12 tahun. Metode penelitian yang digunakan adalah Research and Development (R\&D) yang dilakukan dengan langkah-langkah: 1) Desain Produk, 2) Validasi Tahap ke-1, 3) Revisi Desain, 4) Validasi Tahap Kedua, 5) Uji Coba Produk Skala Kecil, 6) Revisi Produk, 7) Produk Akhir. Sampel penelitian adalah 30 siswa SD Negeri Widarapayung Wetan 02 kelas IV, V, VI. Instrumen penelitian berupa angket berisi pernyataan yang di validasi oleh ahli, kemudian skor yang diperoleh diolah dan dikonversikan ke dalam kriteria penilaian produk. Hasil penelitian ini memperoleh penilaian dari ahli permainan sebesar 94\% atau kategori "Sangat Baik", ahli pendidikan sebesar 90\% atau kategori "Sangat Baik" dan ahli pertumbuhan dan perkembangan sebesar $82 \%$ atau kategori "Sangat Baik", sert penilaian dari guru PJOK sebesar $85 \%$ atau kategori "Sangat Baik", sehingga memperoleh nilai akhir sebesar 91,2\% atau kategori "Sangat Baik", dengan demikian dapat dinyatakan bahwa permainan PPS sangat layak digunakan sebagai model permainan yang berpotensi dapat mengembangkan kemampuan motorik kasar anak usia $9-12$ tahun.
\end{abstract}

\begin{abstract}
Currently traditional games are rarely played by children along with the times, even though several studies mention that traditional games have a very important role in stimulating the gross motor development that is owned by every child. This research aims to create new game products from traditional sport modifications that are appropriate to be used and can potentially develop the gross motor skills of children aged 9-12 years. The research method used is Research and Development (R\&D) which is carried out by the steps of: 1) Product Design, 2) Validation Phase 1, 3) Design Revision, 4) Second Stage Validation, 5) Trial of Small Scale Products, 6) Product Revision, 7) Final Product. The research sample was 30 students at Widarapayung Wetan State Elementary School 02 grades IV, V, VI. The research instrument was in the form of a questionnaire containing statements validated by experts, then the scores obtained were processed and converted into product evaluation criteria. The results of this study obtained an assessment of game experts by $94 \%$ or the category of "Very Good", education experts by $90 \%$ or the category of "Very Good" and experts for growth and development by $82 \%$ or the category of "Very Good", as well as an assessment of PJOK teachers by $85 \%$ or "Very Good" category, so as to get a final score of $91.2 \%$ or "Very Good" category, thus it can be stated that the PPS game is very appropriate to be used as a game model that can potentially develop gross motor skills of children aged 9-12 year.
\end{abstract}




\section{PENDAHULUAN}

Dalam pembentukan sistem gerak tubuh, masa anak-anak merupakan fase yang sangat menentukan (sistem motorik) (Lubans et al., 2010). Pada fase ini terjadi peningkatan perkembangan jasmani anak laki-laki dan perempuan yang cepat (Dedi, 2019). Keterampilan bergerak bertambah cepat, mulai dari gerakan otot besar, otot kecil, dan koordinasi. Otot, syaraf, dan susunan kerangka tubuhpun menuju kematangan. (Goodway \& Branta, 2003). Lubaba \& Rohita (2014) menyatakan berdasarkan kecermatan gerak, kemampuan motorik dibagi menjadi dua yaitu motorik kasar dan motorik halus. Motorik kasar adalah gerakan yang banyak menggunakan otot - otot besar yang digunakan untuk melakukan beberapa kegiatan seperti berlari, memanjat, melompat, melempar, dan menangkap (Kamtini \& Kaban, 2016). Anak-anak harus terus diajak untuk melakukan aktivitas yang dapat mengembangkan kemampuan motoriknya untuk dapat membentuk gerak motorik yang baik terutama dalam hal ini adalah motorik kasar (Van Capelle et al., 2017).

Tingkat kemampuan motorik kasar siswa SD Negeri Jombor Lor Sleman Yogyakarta termasuk kategori "sangat rendah" dengan presentase $8 \%$, "rendah" dengan presentase $36 \%$, "sedang" dengan presentase $32 \%$, "tinggi" dengan presentase $8 \%$, dan "sangat tinggi dengan presentase 16\% (Sihono, 2016). Penelitian tersebut menunjukkan tingkat kemampuan motorik kasar anak SD yang memiliki persentase rendah cukup tinggi. Hal ini diperkuat dari hasil studi pendahuluan yang dilakukan kepada 33 siswa kelas IV, V, VI di SD Negeri Widarapayung Wetan 01, Binangun, Cilacap. Observasi dilakukan dengan menguji tingkat motorik kasar siswa menggunakan instrument tes dari (Nurhasan, 2004) yaitu lari 40 meter, lempar tangkap bola tenis, dodging run, standing broad jump, dan berdiri satu kaki. Menggunakan norma penilaian kemampuan motorik menurut (Saifuddin Azwar, 2010). Hasilnya menunjukkan tingkat kemampuan motorik kasar anak tergolong "kurang sekali" sebesar 3\%, "kurang" sebesar 30,3\%, "sedang" sebesar 33,3\%, "baik" sebesar
27,3\%, dan "sangat baik" sebesar 6,1\%.

Saat ini, kemampuan motorik kasar anak SD masih rendah padahal motorik kasar penting bagi anak untuk mengembangkan geraknya (Burhaein, 2017). Oleh karena itu, diperlukan upaya untuk mengatasi masalah tersebut, salah satunya adalah dengan menggunakan permainan sebagai media pembelajaran. Permainan dan olahraga sesuai dengan karakteristik anak-anak yang masih dalam fase bermain, sehingga dengan menggunakan sebuah model permainan, anak diharapkan mampu mengembangkan kemampuan motorikya. Suatu bentuk permainan yang mampu membuat anak aktif bergerak dan dapat dilakukan dengan mudah serta menyenangkan untuk anak dapat membentuk gerak motorik kasar pada usia anak-anak dengan lebih optimal (Festiawan et al., 2019). Permainan tradisional sangat beragam bentuk dan nama sesuai dari mana permainan ini berasal. Namun seiring dengan kemajuan zaman permainan ini berangsur-angsur mengalami kepunahan (Fadli, 2014). Penelitian lain membuktikan bahwa permainan tradisional memiliki peran yang sangat penting dalam merangsang perkembangan motorik kasar yang dimiliki anak, dan dapat mengembangkan kecerdasan intelektual, emosional, serta kreatifitas anak (Karmila, 2016).

Terdapat dua permainan tradisional yang dikembangkan yaitu permainan tradisional Pecah Piring dan Sintren.

Kedua permainan ini merupakan permainan tradisional yang berkembang di daerah Kabupaten Cilacap. Permainan tradisional Pecah Piring merupakan permainan yang dimainkan oleh dua kelompok. Ada yang bertugas menjadi kelompok jaga dan ada yang menjadi kelompok main. Pada awal permainan, yang pertama bermain harus memecahkan susunan tempurung yang diibaratkan sebagai "piring". Setelah tempurung terjatuh "pecah", maka yang bermain berusaha menyusun kembali dengan tantangan dilempar dengan bola oleh rtim lawan, jika terkena bola maka kesempatan menyusun gagal (Nasution \& Siregar, 2017).

Permainan Sintren merupakan permainan tradisional yang berkembang di Kabupaten Cilacap yang hampir mirip dengan permainan 
lompat tali. Kedua permainan ini berbeda nama akan tetapi hampir sama dari segi alat dan peraturannya. Lompat tali adalah permainan tradisional yang sangat populer pada tahun 80an, yang biasa dimainkan oleh tiga sampai sepuluh anak (Achroni, 2012). Permainan lompat tali memiliki pengaruh yang signifikan terhadap perkembangan motorik kasar pada anak (Anggraini et al., 2018). Berdasarkan kesamaan tersebut maka permainan Sintren juga memiliki potensi untuk dapat mengembangkan kemampuan motorik kasar pada anak.

Melihat potensi dari permainan tradisional Pecah Piring dan Sintren maka dibuatlah modifikasi permainan dari kedua permainan tersebut. Modifikasi ini bertujuan untuk dapat menciptakan suatu model permainan baru yang memiliki unsur-unsur pembentuk kemampuan motorik kasar anak. Keterampilan lain yang berpotensi dapat dikembangkan dalam permainan adalah keterampilan close motor skill yaitu pada saat melempar ke susunan pecahan genteng di awal permainan dan open motor skill saat bisa mengenai susunan pecahan genteng lalu memulai permainan. Menurut (Freitas et al., 2018) menjelaskan bahwa 1) Keterampilan gerak tertutup (close motor skill) merupakan keterampilan gerak dengan stimulus terjadi pada lingkungan yang stabil dan gerakan timbul dari dalam diri sendiri, misalnya melempar, berlari, memanjat. 2) Keterampilan terbuka (open motor skill) merupakan keterampilan gerak yang yang terjadi pada lingkungan yang berubah-ubah menyesuaikan dengan stimulus di lingkungannya, misalnya bermain bulutangkis, sepak bola. Untuk menghasilkan permainan yang dapat memperbaiki kekurangan pada permainan sebelumnya, maka diperlukan modifikasi dengan cara mengkombinasikan dan memodifikasi alat serta peraturan permainan dari dua permainan tersebut. Maka dari itu penulis sangat tertarik untuk melakukan penelitian dengan tema "Pengembangan Model Permainan Pecah Piring Sintren (PPS) untuk Anak Usia 9 - 12 Tahun".

\section{METODE}

\section{Jenis penelitian}

Penelitian ini menggunakan metode penelitian Research and Development (R \& D) yang di modifikasi dari (Sugiyono, 2016). Langkah-langkah penelitian dan pengembangannya sebagai berikut :

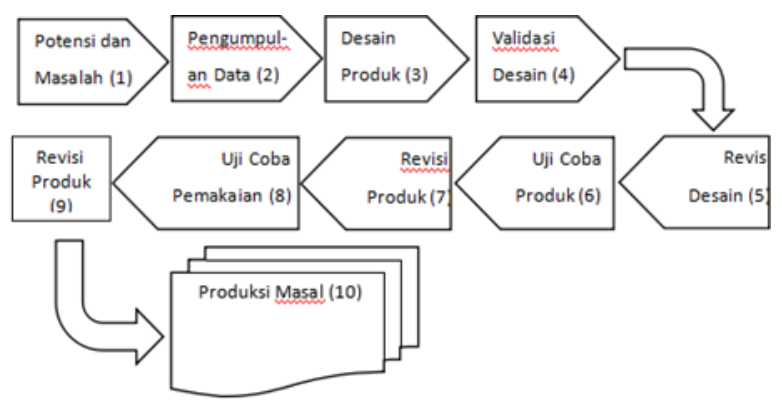

Gambar 1. Langkah Penelitian R \& D

Penelitian ini hanya melaksanakan langkah $1-6$ saja karena pada tahap ini produk sudah melewati tahap uji validasi dan penilaian produk dari user, sehingga sudah dapat diketahui produk layak digunakan atau tidak. Langkah-langkah dalam penelitian ini dapat dilihat pada gambar 2 dibawah ini.

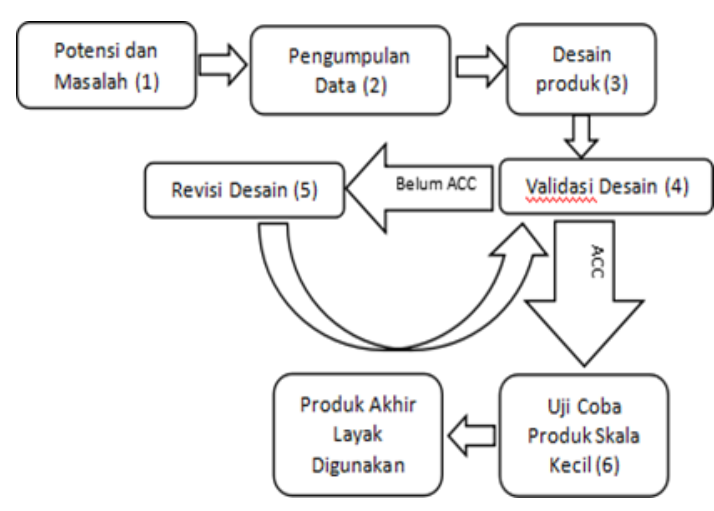

Gambar 2. Model Pengembangan Permainan

\section{Prosedur Penelitian}

Berdasarkan langkah-langkah penelitian pengembangan yang dikemukakan oleh (Sugiyono, 2016), maka prosedur penelitian pengembangan ini dapat disederhanakan ke dalam tahap-tahap berikut ini: 


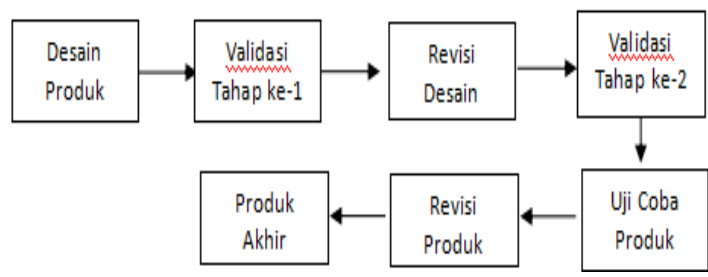

Gambar 3. Tahap-tahap Metode Penelitian

Rangkaian tahap-tahap secara lebih rinci dijabarkan sebagai berikut :

\section{Desain Produk}

Tahap ini merupakan tahap merancang draft desain produk yang sesuai dengan potensi dan masalah yang ada. kemudian membuat peraturan permainan dan sarana prasarana penunjang permainan yang sesuai untuk anak usia 9-12 tahun. Hasil yang telah diperoleh digunakan sebagai acuan untuk menentukan desain produk. Penyusunan draft desain produk terdiri dari beberapa tahapan, antara lain:

\section{Penyusunan Indikator Keberhasilan Desain}

Tahap yang pertama adalah menyusun indikator keberhasilan desain yang dilakukan oleh penulis dibantu oleh ahli yang juga sebagai validator untuk menetapkan standar dari indikator keberhasilan produk.

\section{Menentukan Desain Permainan}

Pembuatan desain permainan meliputi: 1) peraturan permainan, 2) sarana dan prasarana yang dibutuhkan mulai dari alat dan bahan, dan 3) bentuk lapangan $p$ ermainan. Desain ini dibuat agar dapat dimainkan dengan mudah dan menyenangkan serta berpotensi untuk dapat meningkatkan kemampuan motorik kasar anak usia 9-12 tahun.

\section{Perancangan Peraturan Permainan dan Ilustrasi Gambar}

Tahap perancangan peraturan permainan dan ilustrasi gambar desain. $\mathrm{P}$ peraturan permainan dibuat dengan bahasa yang mudah dipahami oleh siswa. Ilustrasi gambar digunakan untuk memperjelas peraturan serta sarana dan prasarana yang dibutuhkan. Ilustrasi gambar dibuat menggunakan software Corel Draw.

\section{Pencetakan Draf Permainan}

Tahap terakhir adalah pencetakan draf permainan yang dikembangkan.

\section{Validasi Tahap ke-1}

Desain produk berupa permainan PPS yang akan dikembangkan dilakukan uji kelayakan oleh ahli atau validator untuk mendapatkan nilai dan masukan. Penilaian uji kelayakan diperoleh dari tiga ahli, yaitu: Ahli Permainan, Ahli Pendidikan, Ahli Pertumbuhan dan Perkembangan.

\section{Revisi Desain}

Revisi dilakukan dari hasil penilaian uji kelayakan oleh ahli pada produk awal untuk dapat menghasilkan produk yang lebih baik.

\section{Validasi Tahap ke-2}

Langkah-langkah pada tahap validasi kedua sama dengan tahap validasi pertama, dilakukan penilaian oleh ketiga ahli terhadap produk yang telah direvisi.

\section{Uji Coba Skala Kecil}

Tahap uji coba skala kecil dilakukan setelah produk dinyatakan layak untuk diujicobakan di lapangan oleh ahli permainan, pendidikan serta ahli pertumbuhan dan perkembangan. Uji coba yang dilakukan meliputi penilaian permainan PPS oleh Guru PJOK dan siswa. Instrumen yang digunakan berupa angket penilaian untuk siswa dan guru PJOK SD. Teknik pengambilan data melalui pengisian angket setelah siswa dan guru PJOK mengamati saat siswa memainkan permainan PPS.

\section{Revisi Produk yang Dikembangkan}

Revisi dilakukan berdasarkan masukan dan penilaian dari guru dan siswa saat uji coba skala kecil dilakukan.

\section{Produk Akhir Permainan PPS}

Hasil akhir berupa permainan PPS yang dinyatakan layak sebagai permainan untuk anak usia 9-12 tahun setelah 
melewati validasi ahli dan penilaian guru dan siswa yang juga berpotensi untuk dapat mengembangkan kemampuan motorik kasar anak.

\section{Populasi}

Populasi dalam penelitian ini meliputi Siswa SD Negeri Widarapayung Wetan 01, Kecamatan Binangun, Kabupaten Cilacap yang digunakan untuk melakukan studi pendahuluan serta SD Negeri Widarapayung Wetan 02, Kecamatan Binangun, Kabupaten Cilacap untuk uji coba skala kecil. Pada penelitian ini teknik sampling yang digunakan adalah teknik simple random sampling, sehingga didapatkan sampel siswa Sekolah Dasar kelas IV, V, VI, yang berjumlah 58 siswa dari SD Negeri Widarapayung Wetan 02. Sampel yang diambil adalah siswa yang berusia 9 - 12 tahun, laki-laki dan perempuan di SD Negeri Widarapayung Wetan 02 .

\section{Teknik Pengumpulan Data}

Pada penelitian ini, teknik pengumpulan data terdiri dari beberapa tahap, antara lain:

\section{Pengumpulan Data Validasi Tahap Pertama}

Pengambilan data dilakukan dengan menyerahkan desain produk yang berupa video dan draft desain produk kepada validator. Setelah desain produk diamati oleh para ahli, selanjutnya menyerahkan instrumen uji kelayakan yang telah disiapkan. Hasil yang didapat akan dijadikan acuan dalam merevisi desain produk.

\section{Pengumpulan Data Validasi Tahap Kedua}

Tahap ini dilakukan setelah ada perbaikan desain produk berdasarkan saran dari ahli pada uji validasi tahap pertama. Pengambilan data dilakukan dengan menggunakan instrumen uji kelayakan yang sama seperti validasi tahap pertama disertai dengan hasil desain produk yng telah direvisi. Pada tahap ini para validator ahli akan memutuskan layak tidaknya desain produk untuk di uji cobakan. Apabila desain produk belum layak maka harus dil- akukan revisi kembali.

\section{Pengumpulan Data Uji Coba Produk Oleh Guru dan Siswa}

Setelah desain produk dinyatakan layak oleh para ahli maka prduk bisa diujicobakan skala kecil. Sebelum pengambilan data guru dan siswa dijelaskan terlebih dahulu mengenai teknis permainan dan sarana yang digunakan pada permainan PPS dengan cara demonstrasi. Setelah itu siswa diberi tugas untuk memainkan permainan PPS secara bergantian selama sepuluh menit setiap satu pertandingan. Saat menunggu giliran main anak mengamati jalannya permainan. Satu tim terdiri dari lima anak, sehingga dengan jumlah sampel 30 anak maka terdapat tiga kali pertandingan. Pada saat anak-anak bermain guru bertugas mengamati jalannya permainan. Pengisian angket instrumen $p$ enilaian produk dilakukan secara bersamasama dengan dipandu oleh peneliti.

\section{Analisis Data}

Teknik analisis data pada penelitian ini dilakukan dengan menghitung presentase yang didapatkan, setelah itu selanjutnya hasil yang didapatkan dikonversikan menjadi persentase skor dengan kriteria dari (Festiawan \& Arovah, 2020) seperti pada tabel 1.

Tabel 1. Kriteria Penilaian Produk

\begin{tabular}{llll}
\hline No & Rentang Skor & Nilai & Kategori \\
\hline 1 & $81 \%-100 \%$ & A & Sangat Baik \\
2 & $61 \%-80 \%$ & B & Baik \\
3 & $41 \%-60 \%$ & C & Cukup Baik \\
4 & $21 \%-40 \%$ & D & Kurang Baik \\
5 & $0 \%-20 \%$ & E & Sangat Kurang Baik \\
\hline
\end{tabular}

Tabel 1 menjelaskan tentang rentang skor yang telah didapatkan dari perhitungan sebelumnya kemudian dimasukkan kedalam tabel tersebut sehingga nantinya akan diketahui nilai yang didapatkan dan juga kategori dari nilai yang didapatkan baik ketika uji validasi ahli maupun penilaian siswa dan guru. 


\section{HASIL DAN PEMBAHASAN}

Hasil penelitian terdiri dari hasil penilaian ahli pada tahapan pertama dan kedua, dan penilaian siswa dan guru terhadap buku saku.

\section{Hasil Validasi Ahli Tahap I}

Tahap validasi dilakukan setelah desain produk telah disusun. Validasi dilakukan mengunakan instrumen lembar validasi berupa angket yang telah dinyatakan valid melalui tahap Expert Judgement. Terdapat tiga validator yang menilai kelayakan produk PPS. Hasil validasi ahli pada tahap pertama, diantaranya:

\section{Hasil Validasi Tahap Pertama Ahli Permainan}

Untuk ahli permainan yang menjadi validator dalam penelitian ini adalah dosen dari Program Studi Pendidikan Jasmani, Fakultas Ilmu-Ilmu Kesehatan, Universitas Jenderal Soedirman.

Tabel 2. Hasil Validasi I (Ahli Permainan)

\begin{tabular}{llll}
\hline No & $\begin{array}{l}\text { Aspek yang } \\
\text { Dinilai }\end{array}$ & Presentase & Kategori \\
\hline 1. & $\begin{array}{l}\text { Kelayakan } \\
\text { Aspek Per- } \\
\text { mainan }\end{array}$ & $94 \%$ & $\begin{array}{l}\text { Sangat } \\
\text { Baik }\end{array}$ \\
\hline Skor Total & $94 \%$ & Sangat \\
\hline
\end{tabular}

Dari tabel diatas diketahui bahwa penilaian dari ahli permainan pada validasi I mendapat nilai 94\% dengan kategori sangat baik.

\section{Hasil Validasi Tahap Pertama Ahli Pendidikan}

Untuk ahli pendidikan yang menjadi validator dalam penelitian ini adalah salah satu dosen dari Program Studi Pendidikan Jasmani, Fakultas Ilmu-ilmu Kesehatan, Universitas Jenderal Soedirman.

Tabel 3. Hasil Validasi I (Ahli Pendidikan)

\begin{tabular}{llll}
\hline No & $\begin{array}{l}\text { Aspek yang } \\
\text { Dinilai }\end{array}$ & $\begin{array}{l}\text { Presen- } \\
\text { tase }\end{array}$ & Kategori \\
\hline 1. & $\begin{array}{l}\text { Kelayakan Aspek } \\
\text { Permainan }\end{array}$ & $90 \%$ & $\begin{array}{l}\text { Sangat } \\
\text { Baik }\end{array}$ \\
\hline Skor Total & $90 \%$ & $\begin{array}{l}\text { Sangat } \\
\text { Baik }\end{array}$ \\
\hline
\end{tabular}

Dari tabel 3 diketahui bahwa penilaian dari ahli pendidikan pada validasi I mendapat nilai $90 \%$ dengan kategori sangat baik.

\section{Hasil Validasi Tahap Pertama Ahli Pertumbuhan dan Perkembangan}

Untuk ahli pertumbuhan dan perkembangan yang menjadi validator dalam penelitian ini adalah salah satu dosen dari Program Studi Pendidikan Jasmani, Fakultas Ilmu-Ilmu Kesehatan, Universitas Jenderal Soedirman.

\section{Tabel 4. Hasil Validasi I (Ahli Pertumbuhan} dan Perkembangan)

Dari tabel 4 diketahui bahwa penilaian

\begin{tabular}{llll}
\hline No & $\begin{array}{l}\text { Aspek yang } \\
\text { Dinilai }\end{array}$ & $\begin{array}{l}\text { Presen- } \\
\text { tase }\end{array}$ & Kategori \\
\hline 1. & $\begin{array}{l}\text { Kelayakan } \\
\text { Aspek Per- } \\
\text { mainan }\end{array}$ & $94 \%$ & $\begin{array}{l}\text { Sangat } \\
\text { Baik }\end{array}$ \\
\hline Skor Total & $94 \%$ & $\begin{array}{l}\text { Sangat } \\
\text { Baik }\end{array}$
\end{tabular}

dari ahli pendidikan pada validasi I mendapat nilai $90 \%$ dengan kategori sangat baik.

\section{Revisi Desain}

Revisi desain ini ddasarkan pada saran yang diberikan oleh masing-masing ahli. Hasil revisi desain sebagai berikut:

Tabel 5. Daftar Revisi Desain

\begin{tabular}{|c|c|c|c|}
\hline No & Validator & Saran & Hasil \\
\hline 1. & $\begin{array}{l}\text { Ahli } \\
\text { Permainan }\end{array}$ & $\begin{array}{lr}\text { Alat permainan } \\
\text { dirubah } & \text { dengan } \\
\text { tingkat } & \text { resiko } \\
\text { yang } & \text { lebih } \\
\text { rendah } & \end{array}$ & $\begin{array}{l}\text { Ujung tiang dilindungi } \\
\text { menggunakan busa } \\
\text { berbentuk kubus yang } \\
\text { terbuat dari sendal } \\
\text { bekas. Alat pengait tali } \\
\text { karet dimodifikasi } \\
\text { dengan menggunakan } \\
\text { ember bekas cat } \\
\text { sebagai media } \\
\text { penancap tiang. }\end{array}$ \\
\hline & & & Ujung tiang dilindungi \\
\hline 2. & $\begin{array}{l}\text { Ahli } \\
\text { Pendidikan }\end{array}$ & $\begin{array}{lr}\text { Alat permainan } \\
\text { dirubah } \\
\text { tingkat } & \text { resiko } \\
\text { yang } & \text { lebih } \\
\text { rendah } & \end{array}$ & $\begin{array}{l}\text { menggunakan busa } \\
\text { berbentuk kubus yang } \\
\text { terbuat dari sendal } \\
\text { bekas. Alat pengait tali } \\
\text { karet dimodifikasi } \\
\text { dengan menggunakan } \\
\text { ember bekas cat } \\
\text { sebagai media } \\
\text { penancap tiang. }\end{array}$ \\
\hline
\end{tabular}




\begin{tabular}{|c|c|c|c|}
\hline No. & Validator & Saran & Hasil \\
\hline 3. & $\begin{array}{l}\text { Ahli } \\
\text { Pertumbuha } \\
\text { n dan } \\
\text { Perkemban } \\
\text { gan }\end{array}$ & $\begin{array}{l}\text { Peraturan harus } \\
\text { yang } \\
\text { merangsang } \\
\text { anak untuk } \\
\text { belajar } \\
\text { berstrategi dan } \\
\text { menyelesaikan } \\
\text { masalah saat } \\
\text { dalam } \\
\text { permainan. } \\
\text { Penggunaan } \\
\text { alat permainan } \\
\text { disesuaikan } \\
\text { dengan } \\
\text { karakteristik } \\
\text { anak usia } 9 \text { - } \\
12 \text { tahun. }\end{array}$ & 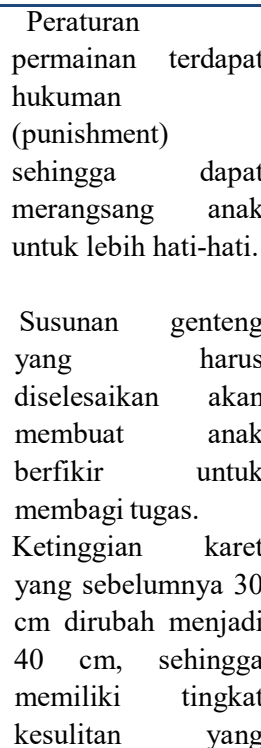 \\
\hline
\end{tabular}

\section{Hasil Validasi Ahli Tahap II}

Hasil penilaian pada tahapan validasi yang kedua dapat dilihat pada Tabel 6 berikut ini.

Tabel 6. Hasil Validasi Tahap II

\begin{tabular}{llll}
\hline No & Ahli & Presentase & Kategori \\
\hline 1. & Permainan & $100 \%$ & Sangat Baik \\
\hline 2 & Pendidikan & $92 \%$ & Sangat Baik \\
\hline 3 & $\begin{array}{l}\text { Pertumbuhan } \\
\text { dan Perkem- } \\
\text { bangan }\end{array}$ & $84 \%$ & Sangat Baik \\
\hline
\end{tabular}

Dari Tabel 6, diketahui bahwa penilaian dari ahli permainan pada tahap validasi kedua mendapatkan nilai $100 \%$ dengan kategori "Sangat Baik", penilaian dari ahli pen

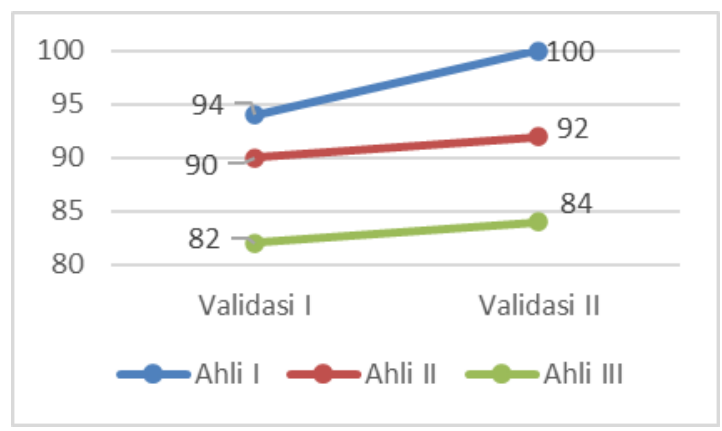

Gambar 4. Grafik Penilaian Ahli Validasi Tahap I dan II didikan mendapatkan nilai $92 \%$ dengan kategori "Sangat Baik", dan penilaian dari ahli pertumbuhan ddan perkembangan mendapatkan nilai 84\% dengan nilai A dan kategori "Sangat Baik". Gambaran nilai yang didapatkan dari validasi tahap pertama dan kedua dapat dilihat pada Gambar 4.

Pada gambar 4, dapat dilihat bahwa Hasil pada validasi tahap kedua berbeda dengan hasil validasi tahap pertama, pada tahap kedua terjadi kenaikan nilai dari seluruh ahli. Dari penilaian ahli permainan naik dari $94 \%$ menjadi $100 \%$, dari ahli pendidikan naik dari $90 \%$ menjasi $92 \%$, sedangkan dari ahli pertumbuhan dan perkembangan naik dari $82 \%$ menjadi $84 \%$.

\section{Uji Coba Produk Skala Kecil}

Tahap ini dilakukan setelah produk dinyatakan layak untuk digunakan pada tahap uji validasi oleh para ahli. hasil dari uji coba produk dapat dilihat sebagai berikut:

Tabel 7. Hasil Uji Coba Produk Oleh Siswa

\begin{tabular}{llll}
\hline No & Persentase Capaian & Frekuensi & Kategori \\
\hline 1. & $85 \%$ & 2 & Sangat Baik \\
2. & $92,5 \%$ & 2 & Sangat Baik \\
3. & $97,5 \%$ & 6 & Sangat Baik \\
4. & $100 \%$ & 20 & Sangat Baik \\
\cline { 1 - 2 } $98 \%$ & 30 & \\
\hline
\end{tabular}

Dilihat dari tabel 7, prosentase yang didapat dari responden "A" sebesar 100\%. Setelah persentase capaian setiap responden diketahui, maka diperoleh rata-rata persentase capain sebesar $98 \%$. Rata-rata dari prosentase capaian ini dikonversikan ke tabel 1 , sehingga dengan hasil 98\% dari kriteria yang diharapkan, dapat dinyatakan bahwa menurut penilaian oleh siswa, pada tahap uji coba produk skala kecil permainan Pecah Piring Sintren (PPS) yang dikembangkan mendapatkan nilai "A" dan kategori "Sangat Baik".

\section{Penilaian oleh Guru PJOK SD}

Tahap ini dilaksanakan setelah guru melakukan pengamatan kepada siswa saat memainkan permainan Pecah Piring Sintren (PPS). Hasil penilaian yang didapatkan dari guru PJOK adalah sebesar 41 dari skor maksimal 
sebesar 50. Maka persentase nilai yang didapat $(\operatorname{Pr})=(41: 50) \times 100 \%=82 \%$. Selanjutnya hasil ini dikonversikan ke dalam kriteria pada Tabel 1. Sehingga dengan hasil $82 \%$ dari kriteria yang diharapkan, dapat dinyatakan bahwa hasil penilaian oleh guru, permainan Pecah Piring Sintren (PPS) yang dikembangkan mendapatkan nilai "A" dan kategori "Sangat Baik".

\section{Pembahasan}

Dari hasil penilaian oleh seluruh ahli, bak ahli permainan, ahli pendidika dan ahli pertumbuhan dan perkembangan, serta penilaian dari siswa dan guru PJOK.. Hasilnya adalah sebagai berikut : $(100 \%+92 \%+84 \%+98 \%+$ $82 \%): 5=91,2 \%$. Penilaian akhir ini didapatkan dengan rata-rata hasil keseluruhan penilaian dari ahli permainan, ahli pendidikan, ahli pertumbuhan dan perkembangan, serta hasil uji coba produk skala kecil oleh siswa dan guru PJOK, sehingga dengan hasil 91,2\% menunjukkan produk akhir permainan Pecah Piring Sintren (PPS) mendapatkan nilai "A" dengan kategori "Sangat Baik", dengan demikian dapat dinyatakan permainan PPS sangat layak digunakan sebagai model permainan untuk meningkatkan kemampuan motorik kasar anak usia 9-12 tahun.

Hasil penelitian ini sejalan dengan penelitan dari (Mahfud et al., 2020), Nilai yang didapatkan adalah $82 \%$ yang dinyatakan valid dan layak untuk digunakan. Berdasarkan hasil pengembangan dapat disimpulkan: (1) Dapat digunakan sebagai salah satu acuan guna meningkatkan keterampilan motoric siswa. (2) Model yang dihasilkan memiliki beberapa variasi dengan menggunakan permainan tradisional. (3) Model ini akan meningkatkan minat anak dalam mengikuti, karena bentuk latihannya dikemas dalam bentuk permainan yang menyenangkan. (4) Ikut melestarikan budaya bangsa khususnya permainan tradisional. (5) Sumbangan bagi ilmu pendidikan khususnya bidang olahraga.

Penelitian lain dari (Hasbi \& Sukoco, 2014) mendapatkan hasil model pembelajaran motorik dengan modifikasi permainan tradisional untuk sekolah dasar kelas atas direspon baik dan efektif. Hal ini dibuktikan dengan persentase pada setiap data kuantitatif di atas $70 \%$ pada skala besar. Respon peserta didik menghasilkan respon positif dan dapat digunakan dalam pembelajaran. Sementara itu penelitian (Widodo \& Lumintuarso, 2017) Berdasarkan penilaian para ahli materi dan guru penjasorkes dapat disimpulkan bahwa pengembangan model permainan tradisional yang disusun sangat baik dan efektif, sehingga model permainan layak digunakan untuk pembelajaran pendidikan jasmani pada siswa.

Penelitian lainnya menyebutkan bahwa model permainan tradisional "boy-boyan" pada pembelajaran dapat meningkatkan indikator perkembangan sosial seperti adanya inisiatif untuk beraktivitas dengan teman sebaya, bergabung dalam permainan, memelihara peran dalam bermain, mengatasi konflik dalam bermain serta mengingatkan kembali perminan tradisional "boy-boyan" ke dunia pendidikan di zaman modern ini (Saleh et al., 2017).

\section{KESIMPULAN}

Setelah produk permainan Pecah Piring Sintren (PPS) melalui tahap uji validasi dan uji coba produk skala kecil, maka dapat disimpulkan bahwa nilai keseluruhan produk akhir permainan PPS adalah 91,2\% atau kategori "Sangat Baik". Sehingga permainan Pecah Piring Sintren (PPS) dinyatakan sangat layak digunakan dan berpotensi untuk mengembangkan kemampuan motorik kasar pada anak usia 9 -12 tahun.

\section{DAFTAR PUSTAKA}

Anggraini, M. A., Karyanto, Y., \& A.S, W. K. (2018). Pengaruh Permainan Tradisional Lompat Tali terhadap Perkembangan Motorik Kasar Anak Usia 5-6 Tahun. Journal of Early Childhood Care and Education, 1(1), 18. https://doi.org/10.26555/jecce.v1i1.60

Burhaein, E. (2017). Aktivitas Fisik Olahraga untuk Pertumbuhan dan Perkembangan Siswa SD. Indonesian Journal of Primary Education, 1 (1), $\quad 51 . \quad$ https://doi.org/10.17509/ ijpe.v1i1.7497

Dedi, S. (2019). Traditional Games Activities to Develop Fundamental Movement Skills of Elementary School Students. Pendidikan Jasmani Olahraga, 3(1), 122-128. https:// doi.org/10.17509/jpjo.v3i1.10461

Fadli, Z. (2014). Membentuk Karakter Anak dengan Olahraga Tradisional. Jurnal Ilmu Keolahragaan, 13(2), 38-44.

Festiawan, R. (2015). Pedagogi Olahraga (Sport 
Pedagogy). Universitas Negeri Yogyakarta.

Festiawan, R. (2020). Kaitan Studi Gerak Manusia, Kesehatan, Aktivitas Fisik dan Pembelajaran Motorik. Universitas Jenderal Soedirman.

Festiawan, R., \& Arovah, N. I. (2020). Pengembangan " Buku Saku Pintar Gizi " Untuk Siswa : Alternatif Media Pembelajaran untuk Meningkatkan Pengetahuan Gizi Olahraga. Physical Activity Journal, 2(1), 188-201. https://doi.org/https:// doi.org/10.32424/1.paju.2020.1.2.2436

Festiawan, R., Ngadiman, N., Kusuma, I. J., Nurcahyo, P. J., \& Kusnandar, K. (2019). Pengembangan Model Pembelajaran Pendidikan Jasmani Berbasis Games, Education, and Visualisation (GEV) Untuk Meningkatkan Pengetahuan Kesehatan Reproduksi Remaja. Jendela Olahraga, 4(2), 13-25. https:// doi.org/10.26877/jo.v4i2.3678

Freitas, D. L., Lausen, B., Maia, J. A., Gouveia, R., Antunes, A. M., Thomis, M., Lefevre, J., \& Malina, R. M. (2018). Skeletal maturation, fundamental motor skills, and motor performance in preschool children. Scandinavian Journal of Medicine and Science in Sports, 28 (11), 2358-2368. https://doi.org/10.1111/ sms. 13233

Goodway, J. D., \& Branta, C. F. (2003). Influence of a motor skill intervention on fundamental motor skill development of disadvantaged preschool children. Research Quarterly for Exercise and Sport. https:// doi.org/10.1080/02701367.2003.10609062

Hasbi, \& Sukoco, P. (2014). Jurnal Keolahragaan, Volume 2 - Nomor 1, 2014. Jurnal Keolahragaan, 2(1), 46-58.

Kamtini, \& Kaban, D. (2016). Pengaruh Permainan Tradisional Lompat Tali Terhadap Perkembangan Motorik Kasar Anak Usia 5-6 Tahun Di TK Santa Lusia Medan T / A 2015 / 2016. Skripsi . Fakultas Ilmu Pendidikan Universitas Negeri Medan . 2016. Bunga Rampai Usia Emas, 2(1), 60-77.

Karmila, M. (2016). Upaya Guru Meningkatkan Motorik Kasar Melalui Permainan Tradisional Pada Anak Usia Dini Usia 5-6 Tahun Dikober Geger Sunten. Jurnal EMPOWERMENT, 5 (2252), 31-50.

Lubaba, S., \& Rohita, R. (2014). Pengembangan Permainan Gobak Sodor Modifikasi Terhadap Kemampuan Motorik Kasar Anak Usia 5-6 Tahun Di Tk Kecamatan Sekaran Lamongan. PAUD Teratai, 3(3), 1-5.

Lubans, D. R., Morgan, P. J., Cliff, D. P., Barnett, L. M., \& Okely, A. D. (2010). Fundamental movement skills in children and adolescents: Review of associated health benefits. Sports Medicine, 40(12), 1019-1035. https:// doi.org/10.2165/11536850-000000000-00000

Mahfud, I., Fahrizqi, E. B., Olahraga, P., Teknokrat,
U., Ratu, L., Bandar, K., Olahraga, P., Teknokrat, U., Ratu, L., \& Bandar, K. (2020). Pengembangan Model Latihan Keterampilan Motorik Melalui Olahraga Tradisional Untuk Siswa Sekolah Dasar. Sport Science And Education Journal, 1(1), 31-37.

Nasution, R. K., \& Siregar, N. I. (2017). Pengaruh Permainan Tradisional Pecah Piring Dan Ular Naga Terhadap Kecerdasan Interpersonal Anak Usia Dini. Analitika, 5(1), 18-25. https://doi.org/10.31289/ ANALITIKA.V5I1.822.G784

Saleh, Y. T., Nugraha, M. F., \& Nurfitriani, M. (2017). Model Permainan Tradisional "Boyboyan" untuk Meningkatkan Perkembangan Sosial Anak SD. Pendidikan Dan Pembelajaran Sekolah Dasar, 1(2b), 127-138. http:// journal.um-surabaya.ac.id/index.php/pgsd/ article/view/1062

Sugiyono. (2016). Metodologi Penelitian Kuantitatif, Kualitatif, dan R\&D. In CV Alfabeta. https:// doi.org/https://doi.org/10.3929/ethz-b000238666

Van Capelle, A., Broderick, C. R., van Doorn, N., E.Ward, R., \& Parmenter, B. J. (2017). Interventions to improve fundamental motor skills in pre-school aged children: A systematic review and meta-analysis. Journal of Science and Medicine in Sport, 20(7), 658-666. https://doi.org/10.1016/j.jsams.2016.11.008

Widodo, P., \& Lumintuarso, R. (2017). Pengembangan model permainan tradisional untuk membangun karakter pada siswa SD kelas atas. Jurnal Keolahragaan, 5(2), 183-193. https://doi.org/10.21831/jk.v5i2.7215 